\title{
KOMUNIKASI TERAPEUTIK DALAM KONSELING ANTARA KONSELOR DAN PASIEN PENYALAHGUNAAN NARKOBADI KLINIK BADAN NARKOTIKA NASIONAL PROVINSI JAWA BARAT
}

\author{
ADRIO KUSMAREZA ADIM, OKI ACHMAD ISMAIL
}

Fakultas Komunikasi dan Bisnis IImu Komunikasi Telkom University

Jl. Telekomunikasi Dayeuhkolot Bandung 40257

Email: okiahmadismail@gmail.com

ABSTRAK Tujuan penelitian ini adalah untuk mengetahui Komunikasi Terapeutik dalam Konseling antara Konselor dan Pasien Penyalahgunaan Narkoba. Untuk menjawab tujuan penelitian maka di tetapkan 4 fokus Peneliti, yaitu fase pra-interaksi, fase orientasi, fase kerja, dan fase terminasi Komunikasi Terapeutik Konselor dalam Merehabilitasi Pasien Penyalahgunaan Narkoba di Klinik Badan Narkotika Nasional Provinsi Jawa Barat.Penelitian ini menggunakan metode kualitatif deskriptif. Jumlah informan pada penelitian ini empat orang, terdiri dari tiga informan kunci dan satu informan pendukung. Teknik pengumpulan data dalam penelitian ini adalah studi pustaka, internet searching, wawancara mendalam, observasi non-partisipan dan dokumentasi.Hasil penelitianmenunjukan konselor Klinik Badan Narkotika Nasional Provinsi Jawa Barat padafase pra-interaksi dimana konselor mempelajari data-data pasien. Fase orientasi dimana konselor melakukan Screening yaitu pendekatan dan membangun hubungan saling percaya dengan pasien dan Assesment yaitu konselor menjamin keamanan pasien serta membuat rencana layanan konseling, dan fase terminasi dimana layanan konseling seorang pasien penyalahgunaan narkoba telah selesai dan akan dirujuk ke pasca rehabilitasi.

Kata Kunci: Komunikasi Terapeutik, Konseling, Penyalahgunaan Narkoba.

ABSTRACT The purpose of this study was to determine Therapeutic Communication in Counseling between Counselors and Drug Abuse Patients. To answer the research objectives, the four focus of the researcher, namely the pre-interaction phase, the orientation phase, the working phase, and the termination phase of Counselor Therapeutic Communication in Rehabilitating Drug Abuse Patients at the National Narcotics Agency Clinic of West Java Province. This study uses qualitative research methods with descriptive studies. The number of informants in this study were four people, consisting of three key informants and one supporting informant. Data collection techniques used in this study are literature study, internet searching, indepth interviews, non-participant observation and documentation. The results of research conducted by the Clinical Counselor of the National Narcotics Board of West Java Province are the pre-interaction phase where the counselor studies patient data. The orientation phase in which the counselor performs the Screening approach and builds trusting relationships with the patient and the Assessment of

CoverAge:

Journal of Strategic Communication the counselor ensures patient safety as well as establishes a counseling service plan, and a termination phase where a drug abuse counseling service has been completed and will be referred to post-rehabilitation.

Vol. 11, No. 1, Hal. 38-45.

September 2020

Keywords: Therapeutic Communication, Counseling, Substance Abuse

Fakultas Ilmu Komunikasi,

Universitas Pancasila 


\section{PENDAHULUAN}

Permasalahan narkoba semakin membesar di negeri kita ini, ditambah lagi semakin banyaknya jenis narkoba baru yang beredar di Indonesia. Kita harus turut melakukan sesuatu untuk bangsa kita ini salah satunya adalah tidak menggunakan narkoba dan turut serta dalam memerangi penyalahgunaan narkoba di negeri ini.

NAPZA (Narkotika, Psikotropika, dan zat adiktif lain) adalah obat-obatan terlarang yang dapat menyebabkan efek ketagihan dan dapat merusak tubuh serta psikis pengguna. Obatobatan ini hanya digunakan di dunia medis untuk keperluan tertentu dan keperluan penelitian, namun jika digunakan secara sembarangan maka akan menimbulkan efek buruk bahkan fatal seperti yang disebutkan sebelumnya.

Salah satu cara untuk menyembuhkan saudara-saudara kita yang sudah terjerat dalam penyalahgunaan narkoba adalah melalui rehabilitasi yang salah satunya dilakukan di Klinik Badan Narkotika Nasional Provinsi Jawa Barat. Salah satu profesi yang dapat membantu penyembuhan seorang pasien penyalahgunaan narkoba adalah seorang konselor. Konselor adalah suatu profesi yang dapat memberikan konseling sesuai bidang yang dikuasainya, memberikan konseling sesuai bidang yang dikuasainya, dan memberikan motivasi-motivasi yang dibutuhkan kliennya dengan tujuan membuatnya menjadi sembuh/menjadi lebih baik. Orang yang berprofesi sebagai konselor adalah orang-orang yang terlatih dan telah tersertifikasi sebagai konselor yang ahli di bidangnya.

Penyembuhan pasien penyalahgunaan naroba yang dilakukan oleh konselor Klinik BNNP Jawa Barat adalah melalui konseling, dimana konseling itu sendiri adalah pertemuan tatap muka antara konselor dan pasien penyalahgunaan narkoba dan pada saat itu pasien akan menyampaikan keluh kesahnya dan apa yang dia butuhkan, selanjutnya konselor akan memberikan motivasi-motivasi dan solusi untuk permasalahan pasien hingga pasien penyalahgunaan narkoba dapat kembali menjadi orang normal dan tidak menggunakan narkoba lagi.

Jika pasien yang ditanganin adalah seorang pengguna narkoba maka konselor tersebut adalah orang yang melayani konseling para pasien yang pernah menggunakan narkoba dan memberikan penyuluhan tentang narkoba seperti yang ada pada Klinik Badan Narkotika Nasional Provinsi Jawa Barat. Berdasarkan hasil wawancara, pada saat melakukan proses penyembuhan, konselor akan melewati fase-fase komunikasi terapeutik yang terbagi atas 4 fase, yaitu fase pra-interaksi, fase orientasi, fase kerja dan fase terminasi, dimana fase-fase tersebut dilakukan oleh konselor Klinik BNNP Jawa Barat menggunakan konseling.

Komunikasi terapeutik adalah komunikasi yang direncanakan dan dilakukan dengan tujuan penyembuhan pasien (Purwanto dalam Damayanti, 2010 :11), dimana berdasarkan hasil wawancara komunikasi terapeutik ini dilakukan oleh konselor Klinik BNNP Jawa Barat karena pada saat proses menyembuhkan pasien penyalahgunaan narkoba mereka akan melewati fase-fase komunikasi terapeutik.

Pada saat proses fase-fase komunikasi terapeutik dilakukan oleh konselor Klinik BNNP Jawa Barat, komunikasi sangat berperan penting karena mempengaruhi hubungan antara konselor dan pasien dan juga kesembuhan pasiennya. Komunikasi yang baik dan tepat dapat mendukung keberhasilan setiap fase-fase komunikasi terapeutik, dimana jenis komunikasi yang berperan penting disini adalah komunikasi antar pribadi.

Komunikasi antar pribadi terjadi pada saat konselor dan pasien penyalahgunaan narkoba saling bertatap muka dan melakukan proses fasefase komunikasi terapeutik dengan konseling di Klinik BNNP Jawa Barat. Komunikasi antar pribadi membantu konselor untuk mengenal lebih baik pasien penyalahgunaan narkoba karena komunikasi ini bersifat langsung dan dapat dilakukan secara tatap muka dan pasien pun dapat dengan lebih mudah untuk mengekspresikan dirinya kepada konselor dan menyampaikan keluhannya kepada konselor sehingga konselor dapat melakukan langkah yang tepat untuk menyembuhkan pasien.

Proses untuk sembuh dari penyalahgunaan narkoba membutuhkan waktu yang lama. Berdasarkan wawancara yang dilakukan dengan salah satu konselor Klinik BNNP Jawa Barat, untuk pengguna narkoba yang sudah masuk ketahap kecanduan membutuhkan waktu rata-rata empat tahun untuk sembuh dan tidak memiliki keinginan untuk menggunakan narkoba lagi. Namun karena pasien yang ditangani di Klinik BNNP Jawa Barat adalah pasien rawat jalan atau pasien penyalahgunaan narkoba yang masih 
berada ditahap pernah mencoba narkoba dan bukan merupakan pasien yang tergolong pecandu, maka waktu yang dibutuhkan untuk sembuh tidak selama pasien pecandu narkoba.

Berdasarkan dari hasil data penelitian Puslitkes Universitas Indonesia bersama dengan BNN pada tahun 2016 lalu, sekitar 27,32\% pengguna narkoba di Indonesia berasal dari kalangan pelajar dan mahasiswa. Jumlah tersebut kemungkinan meningkat kembali karena banyak beredarnya narkoba jenis baru. Hal ini sangat disayangkan, karena kalangan muda merupakan generasi penerus bangsa.

Pengguna yang sudah memasuki tahap kecanduan akan merasa sakit pada sekujur tubuh bila tidak mengkonsumsi narkoba tersebut. Maka dari itu biasanya individu yang sudah menjadi pecandu akan dibawa ke pusat rehabilitasi narkoba untuk menghentikan kecanduan itu. Upaya untuk rehabilitasi para pemakai narkoba juga tidak mudah, karena kebanyakan dari pecandu selalu memakai kembali narkoba setelah kembali ke masyarakat.

Kecanduan tersebut memang tidak mudah untuk dihilangkan kecuali pada diri individu memiliki kecanduannya tersebut. Pada dasarnya motivasi merupakan lima pengertian yang melingkupi penggerak, alasan-alasan atau dorongan-dorongan dalam diri manusialah yang menyebabkan manusia itu berbuat sesuatu.

Berdasarkan pengertian komunikasi terapeutik menurut Mukhripah Damayanti dalam buku "Komunikasi Terapeutik" yang mengatakan bahwa "komunikasi terapeutik adalah komunikasi yang direncanakan dan dilakukan untuk membantu penyembuhan/pemulihan pasien"(Damayanti, 2010 :11), sehingga peneliti menyimpulkan bahwa konselor di Klinik Badan Narkotika Nasional Provinsi Jawa Barat juga melakukan komunikasi terapeutik dan ini diperkuat oleh hasil pra-riset yaitu wawancara yang menegaskan bahwa konselor di Klinik Badan Narkotika Nasional Provinsi Jawa Barat melakukan komunikasi terapeutik dan melakukan fase-fase komunikasi terapeutik menurut Stuart dan Sundeen, dalam Christina, dkk dalam buku Komunikasi Terapeutik yang menjadi rumusan masalah dalam penelitian ini.

Berdasarkan pemaparan latar belakang diatas, peneliti yakin untuk mengangkat judul penelitian "Komunikasi Terapeutik dalam Konseling antara Konselor dan Pasien Penyalahgunaan Narkoba" dan berharap penelitian ini dapat menjawab rumusan masalah tentang Bagaimana "Komunikasi Terapeutik dalam Konseling antara Konselor dan Pasien Penyalahgunaan Narkoba". Penelitian ini meninjau bagaimana Komunikasi terapeutik dalam konseling antara konselor dan pasien penyalahgunaan narkoba di klinik badan narkotika nasional provinsi jawa barat dengan berfokus pada Bagaimana fase pra-interaksi, Bagaimana fase orientasi Komunikasi Terapeutik, Bagaimana fase kerja Komunikasi Terapeutik, Bagaimana fase terminasi Komunikasi Terapeutik.

\section{TINJAUAN PUSTAKA}

Pengertian komunikasi berasal dari bahasa latin communication yang berarti pemberitahuan, pemberian bagian, pertukaran, ikut ambil bagian, pergaulan, peran serta, atau kerjasama. Asal katanya sendiri berasal dari communis yang berarti common (bersifat umum, sama, atau bersama-sama). Sedangkan kata kerjanya communicare yang berarti berdialog, berunding atau bermusyawarah. Berdasarkan buku mengenai Ilmu Komunikasi, komunikasi menurut Sir Geral Barry (2010:15) menyatakan :

"Dengan komunikasi orang akan memperoleh informasi, pengetahuan, pengalaman, terbentuknya saling pengertian berlangsungnya sebuah percakapan, keyakinan, kepercayaan, dan control juga sangat diperlukan".

Sedangkan menurut Effendi (1993:28) menyatakan :

"Hakikat komunikasi adalah proses pernyataan antar manusia, di mana orang dinyatakan itu adalah pikiran, perasaan seseorang kepada orang lain dengan menggunakan bahasa sebagai alat penyalurnya".

Sementara itu Wilbur Schramm menampilkan apa yang ia sebut "the condition of success in communication", yakni kondisi yang harus dipenuhi jika kita menginginkan agar suatu pesan membangkitkan tanggapan yang kita kehendaki.

Kondisi tersebut dapat dirumuskan sebagai berikut:

1.Pesan harus dirancang dan disampaikan sedemikian rupa, sehingga dapat menarik perhatian komunikan.

2.Pesan harus menggunakan lambang-lambang tertuju kepada pengalaman yang sama antara komunikator dan komunikan, sehingga sama-sama mengerti.

3.Pesan harus membangkitkan kebutuhan 
pribadi komunikan dan menyarankan beberapa cara untuk memperoleh kebutuhan tersebut.

4."Komunikasi terapeutik adalah komunikasi yang direncanakan secara sadar, bertujuan dan kegiatannya difokuskan untuk kesembuhan pasien, dan merupakan komunikasi profesional yang mengarah pada tujuan untuk penyembuhan pasien" (Heri Purwanto, 1994).

Terapeutik merupakan kata sifat yang dihubungkan dengan senidari penyembuhan (As Hornby Dalamintan, 2005). Maka disini dapat diartikan bahwa terapeutik adalah segala sesuatu yang memfasilitasi proses penyembuhan seseorang. Sehingga komunikasi terapeutik itu sendiri dapat di definisikan sebagai komunikasi yang direncanakan dan dilakukan untuk membantu klien atau pasien dalam penyembuhan/pemulihan klien atau pasiennya. Komunikasi terapeutik merupakan komunikasi profesional bagi perawat.

Di dalambukunya Stuart G.W. mengatakan:

"Pada profesi keperawatan komunikasi menjadi sangat penting karena komunikasi merupakan alat dalam melaksanakan proses keperawatan. Dalam asuhan keperawatan, komunikasi ditunjukan untuk mengubah perilaku klien dalam mencapai tingkat kesehatan yang optimal" (Stuart, G.W.,1998).

Dalam membina hubungan terapeutik (berinteraksi) perawat mempunyai empat tahap yang pada setiap tahapannya mempunyai tugas yang harus diselesaikan oleh perawat (Stuart dan Sundeen, dalam Christina, dkk., 2003).

1.Fase Pra-Interaksi. Pra-interaksi merupakan masa persiapan sebelum berhubungan dan berkomunikasi dengan klien.

2.Fase Orintasi/Perkenalan. Perkenalan merupakan kegiatan yang anda lakukan saat pertama kali bertemu dengan klien.

3.Fase Kerja. Fase kerja merupakan inti hubungan perawatan klien yang terkait erat dengan pelaksanaan rencana tindakan keperawatan yang akan dilaksanakan sesuai dangan tujuan yang akan dicapai.

4.FaseTerminasi. Terminasi merupakan akhir dari setiap pertemuan perawat dengan klien. Terminasi dibagi dua, yaitu terminasi sementara dan terminasi akhir.

1.Terminasi Sementara. Terminasi
sementara adalah akhir dari tiap
pertemuan perawat dan klien. Pada
terminasi sementara, perawat akan
bertemu lagi dengan pasien pada waktu

yang telah ditentukan.

2.Terminasi Akhir. Terminasi akhir terjadi jika klien akan pulang dari rumah sakit atau setelah klien selesai praktek dirumah sakit. (Mukhripah Damiyanti, 2008:22)

\section{METODE}

Seorang yang ahli dalam melakukan konseling dimana di Klinik Badan Narkotika Nasional Provinsi Jawa Barat, konselor ahli dalam melakukan konseling dengan pasien penyalahgunaan narkoba.

Pada proses penyembuhannya, konselor menggunakan tahapan komunikasi terapeutik di mana tahapan terapeutik oleh Stuart dan Sundeen dalam buku Komunikasi Terapeutik oleh Mukhripah Damayanti adalah fase pra-interaksi, fase orientasi, fase kerja, dan fase terminasi.

Konselor menggunakan konseling pada saat melakukan 4 fase komunikasi terapeutik, di mana konseling suatu proses dimana pasien belajar bagaimana membuat keputusan dan memformulasikan cara baru untuk bertingkah laku merasa dan berfikir.

Target dari fase-fase komunikasi terapuetik ini adalah pasien, di mana pasien yang datang ke Klinik Badan Narkotika Nasional Provinsi Jawa Barat merupakan pasien penyalahgunaan narkoba.

\section{HASIL DAN PEMBAHASAN}

\section{CommunicationFase Pra-interaksi Komunikasi Terapeutik dalam Konseling antara Konselor dan Pasien Penyalahgunaan Narkoba}

Fase pra-interaksi adalah fase pertama dalam komunikasi terapeutik dan pada fase pra-interaksi yang dilakukan oleh konselor di Klinik Badan Narkotika Nasional Provinsi Jawa Barat, Peneliti mengamati dan mengajukan pertanyaan bagaimana fase pra-interaksi yang dilakukan oleh konselor Klinik Badan Narkotika Nasional Provinsi Jawa Barat dan bagaimana dampaknya jika fase pra-interaksi tidak dilakukan oleh konselor. Hasil dari wawancara bersama informan kunci bahwa fase pra-interaksi hanya dilalui/dilakukan oleh konselor saja dan didalam fase pra-interaksi konselor akan mempelajari data-data pasien melalui formulir yang akan diisi pada saat administrasi. Berikut pembahasannya :

\section{Narkoba}

Mempelajari Data Pasien Penyalahgunaan

Data seperti umur pasien penyalahgunaan narkoba dapat membantu konselor dalam mengetahui kemungkinan pemakaian obat-obatan terlarang pasien penyalahgunaan narkoba tersebut, karena dengan mengetahui umur saja, konselor bisa 
mengetahui kemungkinan jenis obat apa yang pasien tersebut gunakan. Menurut Peneliti hubungan umur dengan jenis obat-obatan terlarang adalah berdasarkan pengalaman klinik karena sudah sering melakukan layanan konseling dengan pasien-pasien yang memiliki keberagaman pada umurnya. Pasien berusia muda yang ditangani klinik sebelum-sebelumnya misalnya menggunakan obat-obatan terlarang seperti ganja dan shabu, maka klinik dapat menyimpulkan dari hal tersebut bahwa pasien penyalahgunaan narkoba yang berusia muda biasanya menggunakan ganja dan shabu. Bagitu juga dengan pasien penyalahgunaan narkoba yang berusia dewasa sebelum-sebelumnya misalnya menggunakan obat-obatan terlarang seperti heroin dan morfin, maka klinik dapat menyimpulkan bahwa pasien penyalahgunaan narkoba yang berusia dewasa biasanya akan menggunakan heroin dan morfin.

Menurut Peneliti, selain data mengenai pekerjaan pasien dapat membantu konselor dalam pendekatan nanti, konselor juga akan bisa mendapat gambaran untuk jadwal pertemuan layanan pasien tersebut, misalnya pasien tersebut adalah seseorang yang masih bekerja, maka konselor akan mendapat gambaran bahwa nantinya jadwal pertemuan layanan dengan pasien tersebut adalah pada hari Jumat karena biasanya pada hari Jumat orang yang bekerja akan pulang tidak terlalu sore atau pasien tersebut diberikan oleh tempat dia bekerja hari dimana dia melakukan layanan konseling.

Data-data pasien penyalahgunaan narkoba juga dapat memperlihatkan apakah pasien tersebut memerlukan pemeriksaan fisik terlebih dahulu oleh dokter serta mengetahui tujuan yang diinginkan oleh pasien penyalahgunaan narkoba itu sendiri. Menurut Peneliti, konselor dapat mengetahui apakah pemeriksaan fisik diperlukan oleh pasien karena data-data pasien dapat memperlihatkan keadaan pasien saat itu atau sesuatu yang pernah terjadi pada pasien tersebut, misalnya pasien tersebut pernah menggunakan jarum suntik pada saat mengkonsumsi obat-obatan terlarang, maka pasien tersebut harus dirujuk ke dokter untuk menjalani pemeriksaan sesuai kebutuhan pasien tersebut.

Fase Orientasi Komunikasi Terapeutik dalam Konseling antara Konselor dan Pasien Penyalahgunaan Narkoba

\section{Screening}

Pada saat masuk ke fase orientasi, konselor dan pasien akan bertemu dan melakukan pendekatan. Screening merupakan fase pendekatan dimana tujuannya adalah membangun trust atau hubungan saling percaya dengan pasien penyalahgunaan narkoba dan menggali lebih jauh data-data yang diperlukan konselor demi kepentingan proses konseling nanti, seperti permasalahan yang dihadapi pasien penyalahgunaan narkoba tersebut, latar belakang pasien dan keluhan pasien.

\section{Assesment}

Setelah konselor melakukan pendekatan untuk mengenal lebih jauh pasiennya serta membangun trust atau hubungan saling percaya dengan pasien, konselor dan pasien penyalahgunaan narkoba akan melanjutkan fase orientasi ke tahap assesment, dimana pada tahap assesment, konselor akan membuat pasien merasa aman dan menetapkan rencana konseling selama kedepannya bersama pasien.

Selain membuat pasien penyalahgunaan narkoba merasa nyaman bersama konselor di klinik, konselor harus membuat pasien merasa aman juga. Cara konselor membuat pasien penyalahgunaan narkoba merasa aman adalah dengan menjelaskan bahwa pasien dilindungi oleh UU dan Klinik Badan Narkotika Nasional Provinsi Jawa barat sangat menjunjung tinggi asas kerahasiaan.

Selain itu pada tahap assesment, konselor akan membuat rencana layanan konseling bersama pasien penyalahgunaan narkoba. Konselor dan pasien penyalahgunaan narkoba akan menyepakati capaian-capaian yang harus dicapai oleh pasien penyalahgunaan narkoba selama menjalani layanan di Klinik Badan Narkotika Nasional Provinsi Jawa Barat. Capaian-capaian yang disepakati oleh konselor dengan pasien penyalahgunaan narkoba dapat berupa pencapaian yang berbeda-beda tergantung keinginan setiap pasien dan kebutuhan setiap pasien. Lalu terjadilah kepekatan layanan konseling antara konselor dengan pasien penyalahgunaan narkoba.

\section{Fase Kerja Komunikasi Terapeutik dalam Konseling antara Konselor dan Pasien Penyalahgunaan Narkoba \\ Individual Counseling}

Individual counseling itu adalah konseling yang bersifat tatap muka atau secara langsug antara konselor dan pasien penyalahgunaan narkoba. Konselor akan membantu pasien dalam menyelesaikan permasalahan yang pasien ceritakan pada konselor. Konselor akan mengurangi rasa bersalah pasien atau penilaian negatif terhadap dirinya serta penilaian negatif terhadap lingkungan atau orang-orang di sekelilingnya. 
Reflection adalah cara yang dilakukan konselor untuk mengembalikan kembali apa yang pasien katakan dan menanyakan kembali apakah tindakan pasien tersebut benar menurut pasien itu sendiri. Konselor akan membuat pasien berfikir kembali tentang apa yang telah dia lakukan dan apakah yang dia lakukan itu benar atau salah.

Selain teknik-teknik diatas, Peneliti menemukan juga teknik lain yaitu teknik Motivational Interviewing. Teknik ini adalah dimana konselor membantu pasien mengksplorasi dan memutuskan keragu-raguannya tentang penggunaan zatnya dan mulai untuk membuat perubahan yang positif. Peneliti melihat bahwa teknik ini akan sangat membantu pasien-pasien yang masih berstatus pecandu biasa maupun pecanu berat, dimana konselor akan memberikan motivasi-motivasi berupa dukungan dan informasi yang membuat pasien yakin untuk membuat perubahan positif pada dirinya yaitu menurunkan dosis penggunaan obat-obat terlarang dan bahkan berhenti menggunakannya.

Setelah itu ada teknik lain yang disebut CBT (Cognitive Behavioral), teknik ini berupa komunikasi yang dilakukan konselor kepada pasien dan teknik ini hampir sama dengan Motivational Interviewing. Pasien akan diajarkan, didorong, dan didukung untuk mengurangi atau menghentikan pemakaian obat-obat terlarang pasien.

\section{Group Counseling}

Group counseling adalah saat dimana pasien akan akan dikumpulkan dengan pasien lain dan masing-masing konselor akan melihat masingmasing pasiennya pada saat mereka berkumpul dan saling berkomunikasi. Pasien penyalahgunaan narkoba tersebut dikumpulkan berdasarkan usia, dimana usia mereka yang sama atau tidak berbeda jauh satu sama lain. Dikumpulkannya itu biasanya dilakukan di luar klinik, dimana mereka akan merasa nyaman. Pada saat sesi tersebut terjadi para konselor akan mengobservasi para pasiennya masing-masing dan membuat penilaian untuk memprogres perubahan masing-masing pasien.

Fase Terminasi Komunikasi Terapeutik dalam Konseling antara Konselor dan Pasien
Penyalahgunaan Narkoba

\section{Terminasi Sementara}

Pada terminasi sementara di Klinik Badan Narkotika Nasional Provinsi Jawa Barat biasanya pasien akan diberikan tugas. Tugas yang diberikan akan berbeda-beda tergantung pada permasalahan dan kebutuhan pasien. Berdasarkan hasil dari wawancara dengan informan kunci, tugas yang diberikan dapat berupa membuat jurnal mengenai sesuatu, dapat kembali mengakses layanan pendidikan seperti kembali bisa bersekolah dan dapat bergaul dengan orang-orang dilingkungannya, dan berkenalan dengan orang baru di lingkungan yang baru juga. Peneliti melihat tugas-tugas yang diberikan konselor kepada pasien adalah untuk membuat perubahan positif dalam diri pasien dan untuk membantu pasien mencegah keinginan pasien untuk menggunakan obat-obatan terlarang.

\section{Terminasi Akhir}

Berdasarkan hasil wawancara dengan para informan kunci, terminasi akhir adalah terminasi yang dilakukan ketika masa layanan seorang pasien telah selesai. Di Klinik Badan Narkotika Nasional terdapat misi, dimana salah satu misi mereka adalah menyelenggarakan rujukan pecandu ke layanan yang lebih komprehensif sesuai dengan tingkat ketergantungan dan kondisi penyalahgunaan narkoba.

Berdasarkan misi tersebut klinik wajib melakukan rujukan, dimana rujukan yang dilakukan pada fase terminasi akhir ini adalah rujukan untuk melanjutkan layanan ke pasca rehabilitasi yaitu rumah damping, dimana pasien akan menjalani rawat inap.

\section{Komunikasi Terapeutik dalam Konseling antara Konselor dan Pasien Penyalahgunaan Narkoba}

Komunikasi Terapeutik dalam Konseling antara Konselor dan Pasien Penyalahgunaan Narkoba yang dilakukan di Klinik BNNP Jabar adalah 4 fase komunikasi terapeutik, yaitu fase pra-interaksi yaitu fase dimana konselor mempelajari data-data pasien sehingga menghasilkan kesiapan konselor. Fase orientasi, yaitu fase dimana konselor dan pasien penyalahgunaan narkoba melakukan tahap screening dan assesment sehingga menghasilkan kesepakatan layanan konseling. Fase kerja, yaitu fase dimana konselor dan pasien penyalahgunaan narkoba menjalani tahap individual counseling dan group counseling sehingga menghasilkan pencapaian layanan konseling. Fase terminasi, yaitu fase terkahir dan dibagi menjadi 2 macam terminasi yaitu terminasi sementara yaitu terminasi yang dilakukan setiap pertemuan berkahir dan terminasi akhir yaitu terminasi yang dilakukan pada saat keseluruhan pertemuan selesai.

\section{SIMPULAN}

Berdasarkan hasil penelitian pada bab IV telah diangkat subfokus yang menjelaskan Komunikasi Terpeutik dalam Konseling antara Konselor dan Pasien Penyalahgunaan Narkoba,maka dapat ditarik kesimpulan sebagai berikut :

1. Fase pra-interaksi yang dilakukan oleh konselor Klinik Badan Narkotika Nasional Provinsi Jawa 
Barat mempelajari data pasien penyalahgunaan narkoba. Data seperti nama, umur, dan obat terlarang yang digunakan pasien merupakan data-data yang sangat penting. Persiapan konselor akan semakin baik jika mempelajari data-data pasien terlebih dahulu.

2.Fase orientasi yang dilakukan oleh konselor Klinik Badan Narkotika Nasional Provinsi Jawa Barat terbagi menjadi 2, yaitu screening dan assesment. Screening dilakukan untuk melakukan pendekatan dengan pasien penyalahgunaan narkoba dan menjadi hubungan "trust" atau hubungan saling percaya. Sedangkan assesment adalah dimana konselor menjamin keamanan pasien dengan menjelaskan bahwa pasien penyalahgunaan narkoba telah dilindungi oleh UU yang mengatur tentang rehabilitasi dan pasien penyalahgunaan narkoba pada pasal 54 dan 55 bagian kedua pada bab IX mengenai pengobatan dan rehabilitasi. Selain itu pada assesment konselor Klinik Badan Narkotika Nasional Provinsi Jawa Barat melakukan penetapan rencana layanan konseling bersama dengan pasien.

3. Fase kerja yang dilakukan oleh konselor Klinik Badan Narkotika Nasional Provinsi Jawa Barat terbagi menjadi 2 jenis konseling, yaitu individual counseling dan group counseling. Pada individual counseling konselor menggunakan beberapa teknik konseling seperti reflection yaitu dimana konselor akan mengembalikan kembali apa yang pasien katakan dan menanyakan kembali apakah tindakan pasien tersebut benar menurut pasien itu sendiri. Konselor akan membuat pasien berfikir kembali tentang apa yang telah dia lakukan dan apakah yang dia lakukan itu benar atau salah, motivational interviewing yaitu dimana konselor membantu pasien mengksplorasi dan memutuskan keraguraguannya tentang penggunaan zatnya dan mulai untuk membuat perubahan yang positif., dan cognitive behavioral therapy yaitu dimana konselor akan mengajarkan, mendorong, dan menduku pasien untuk mengurangi atau menhentikan pemakaian obat-obatan terlarang.Sedangkan group counseling adalah dimana konselor melakukan penilaian kepada pasiennya saat bekumpul dengan pasien-pasien lainnya bersama dengan konselor-konselor lainnya juga.

4. Fase terminasi yang dilakukan konselor Klinik Badan Narkotika Nasional Provinsi Jawa Barat terbagi menjadi 2, yaitu terminasi sementara dan terminasi akhir. Terminasi sementara dilakukan oleh konselor Klinik Badan Narkotika Nasional Provinsi Jawa Barat setiap pertemuan dengan pasien penyalahgunaan narkoba berakhir dan konselor akan memberikan tugas kepada pasien serta menetapkan waktu pertemuan berikutnya.

Terminasi akhir dilakukan konselor pada akhir layanan konseling, dimana pasien dianggap telah mencapai capaian layanannya. Pasien akan dirujuk ke pasca rehabilitasi yaitu rumah damping sesuai dengan misi Klinik Badan Narkotika Nasional Provinsi Jawa Barat. Namun tidak semua pasien bisa melanjutkan ke pasca rehabilitasi dikarenakan sibuk bekerja atau kesibukan lainnya, serta pasien yang sudah bisa mandiri dan produktif.

5. Komunikasi Terapeutik dalam Konseling antara Konselor dan Pasien Penyalahgunaan Narkoba di Klinik Badan Narkotika Nasional Provinsi Jawa Barat melakukan 4 fase komunikasi terapeutik yaitu fase pra-interaksi dimana konselor mempelajari data-data pasien. Fase orientasi dimana konselor melakukan Screening yaitu pendekatan dan membangun hubungan saling percaya dengan pasien dan Assesment yaitu konselor menjamin keamanan pasien serta membuat rencana layanan konseling, dan fase terminasi dimana layanan konseling seorang pasien penyalahgunaan narkoba telah selesai dan akan dirujuk ke pasca rehabilitasi.

\section{DAFTAR PUSTAKA}

Arwani.(2003). Komunikasi Dalam Keperawatan. Jakarta : Penerbit Buku Kedokteran EGC.

Azmiyati, SR, dkk.(2014). Gambaran Penggunaan NAPZA pada Anak Jalanan di Kota Semarang. Jurnal Kesehatan Masyarakat (KEMAS), 9 (2): 137-147.

Creswell, J.W. (2010). Research Design, Pendekatan Kualitatif, Kuantitatif, dan Mixed.Yogyakarta:Pustaka Pelajar

Damayanti, M. (2008). Komunikasi Terapeutik dalam Praktik Keperawatan. Bandung : PT. Refika Aditama.

Dewi, J. A. 2014. Komunikasi Terapeutik Pada Anak Penyandang Down Syndrome. Skripsi.

Hawari, D. (2000). Penyalahgunaan dan Ketergantungan NAZA. Balai Penerbit FK. UI. Jakarta.

Kurniawati, Rd. Nia Kania. (2014). Komunikasi Antarpribadi: Konsep dan Teori Dasar. Yogyakarta: Graha Ilmu. 
Kusuma, A. W. (2016). Komunikasi Terapeutik Pasien Skizofrenia. Skripsi.

Liliweri, Allo. (2002). Komunikasi Antar Pribadi. Bandung : PT. Citra Aditya Bakti.

Muninjaya, A.A. Gde. Manajemen Kesehatan. Jakarta : Buku Kedokteran EGC.

Mulyana, D. (2012). Ilmu Komunikasi, Suatu pengantar.Bandung:PT Remaja Rosdakarya.

Mulyana, D. (2008). Metode Penelitian Komunikasi. Bandung :PT Remaja Rosdakarya.

Moleong, L. J. (2006). Metodelogi Penelitian Kualitatif (Edisi Revisi). Bandung: PT.Remaja Rosdakarya.

Nelson-Jones, R. (2012).Pengantar Keterampilan Konseling. Yogyakarta : Pustaka Pelajar.

Nainggolan, T. G. (2015). Hubungan Komunikasi Terapeutik Perawat dengan Kepuasan Pasien Pada Pelayanan Keperawatan di RSUD Sidikalang. Skripsi.

Pitojo, S. (2006). Ganja, Opium, dan Coca Komoditas Terlarang. Bandung: Penerbit Angkasa.

Supriadi \& Indrawati, E. (2011). Psikologi Konseling. Jakarta : Inti Prima Promosindo . 